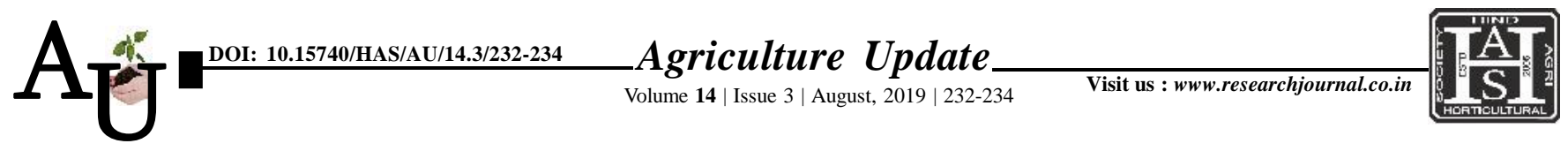

ISSN-0973-1520

\title{
Reserkch Article: Impact of Krishi Vigyan Kendra programme on beneficiaries
}

\author{
V. V. Holkar, V. V. Gohad, P. A. Ingawale and S. D. Mohokar
}

Article Chronicle : Received :

04.06.2019;

Revised :

09.07.2019;

Accepted :

19.07.2019

KEY WoRds:

Krishi Vigyan Kendra, Beneficiaries, Imapct
SUMMARY : For the study, Amravati district was selected purposively. Krishi Vigyan Kendra, Durgapur (Badnera) purposively selected for study. From each Krishi Vigyan Kendra adopted villages, 10 farmers were selected randomly after receiving its beneficiaries list from Krishi Vigyan Kendra and 10 each from non-adopted villages, each total to the tune $40+40=80$. Ex-post facto research design was used for the study. The finding of study revealed that, the majority of beneficiaries had higher annual income 92.5 per cent (Kulkarni, 2009), more social participation 57.5 per cent, more market orientation 87.5 per cent, high risk orientation 72.5 per cent than the non-beneficiaries. It was also observed that there was no difference in respect of farming experience between beneficiaries and non-beneficiaries i.e. 72.50 per cent (Kulkarni, 2009). While it was observed that non-beneficiaries were found more educated 30 per cent than beneficiaries. Non-beneficiaries had more land holding 22.50 per cent than beneficiaries 2.50 per cent. As regard the dependent variable, majority of the beneficiaries 80.00 per cent had more impact of KVK programme than non-beneficiaries 62.50 per cent. The study revealed that, the independent variables namely education, land holding, annual income, farming experience, market orientation was found positive and significant with the impact of KVK programme at 0.05 per cent level of probability. Whereas the independent variabers namely social participation and extension contact was found positively and significant relationship with the impact of KVK programme at 0.01 per cent level of probability. The variable risk orientation was non-significant to impact.

How to cite this article : Holkar, V.V., Gohad, V.V., Ingawale, P.A. and Mohokar, S.D. (2019). Impact of Krishi Vigyan Kendra programme on beneficiaries. Agric. Update, 14(3): 232-234; DOI : 10.15740/HAS/AU/14.3/232234. Copyright@ 2019: Hind Agri-Horticultural Society.
Author for correspondence :

\section{V.V. Gohad}

Department of Extension Education, Shri Shivaji Agriculture College, Amravati (M.S.) India

See end of the article for authors' affiliations 